\title{
Is Articaine More Potent than Mepivacaine for Use in Oral Surgery?
}

\author{
Giath Gazal ${ }^{1}$ \\ Saudi Arabia.

\section{Corresponding Author:} \\ Giath Gazal \\ Department of Oral and Maxillofacial Surgery \\ College of Dentistry, Taibah University \\ Madinah Al Munawwarah \\ Saudi Arabia \\ Phone: 00966532158597 \\ Fax: \\ E-mail: gazal73@yahoo.co.uk
}

${ }^{1}$ Department of Oral and Maxillofacial Surgery, College of Dentistry, Taibah University, Madinah Al-Munawwarah,

\section{ABSTRACT}

Objectives: To investigate the potency and speed of action of $4 \%$ articaine and $2 \%$ mepivacaine for maxillary teeth extractions. Material and Methods: Ninety-four patients, aged between 16 to 70 years old, were recruited in this study. Two regimens were randomly administered over one visit. Patients of treatment group 1 received mepivacaine 2\% with 1:100,000 adrenaline, whereas treatment group 2 - articaine 4\% with 1:100,000 adrenaline. The onset time of pulp anaesthesia for maxillary teeth indicated for extraction was determined by electronic pulp testing. At any point of trial (10 minutes), the anesthetized tooth becomes unresponsive for maximal pulp stimulation (64 reading), the extraction was carried out.

Results: In this study, 85 patients had successful local anaesthetic followed by extraction within the study duration time (10 min). However, 5 patients had failed dental extraction (4 in mepivacaine group and 1 in articaine group). Patients in the articaine buccal infiltration group recorded faster onset time of action regarding anaesthesia and teeth extraction than patients in mepivacaine buccal infiltration group $(\mathrm{P}=0.03)$.

Conclusions: Articaine is an effective anaesthetic with a rapid onset, comparable to mepivacaine in infiltrative techniques used for maxillary teeth extraction. However, articaine has clinically achieved faster dental anaesthesia and earlier teeth extraction than mepivacaine. So, articaine can be the local anaesthetic of first choice in oral surgery.

Keywords: anesthesia; articaine; local anesthesia; mepivacaine; oral surgery; tooth extraction.

Accepted for publication: 28 September 2018

To cite this article:

Giath G.

Is Articaine More Potent than Mepivacaine for Use in Oral Surgery?

J Oral Maxillofac Res 2018;9(3):e5

URL: http://www.ejomr.org/JOMR/archives/2018/3/e5/v9n3e5.pdf

doi: $10.5037 /$ jomr.2018.9305 


\section{INTRODUCTION}

Performance of pain free teeth extraction is still considered such an obsession for both the patients and the dental surgeons [ $[1, \underline{2}]$. Dental researchers are still looking for the optimal local anaesthetic agent which can produce the rapid onset and longer duration $[\underline{3}, 4]$. The literature has no enough evidence about the superiority of $4 \%$ articaine contemporary local anaesthetic drug over 2\% mepivacaine [5-7]. Lugman et al. [ 8$]$ reported that the buccal infiltration with a single articaine injection and lignocaine buccal and palatal infiltration were equally effective for maxillary exodontia. Articaine is different from other amide local anaesthetic because it contains a thiophene ring. The thiophene ring allows greater lipid solubility, which facilitates diffusion across the lipid-rich nerve membrane to access target receptors [9]. The anaesthetic failure in maxilla can be due to pulpitis that results in hyperalgesia in enclosed pulp tissues. Therefore, routine local anaesthetic techniques may not prevent nerve transmission adequately $[\underline{10}, \underline{11}]$. Articaine buccal infiltration provided significant improvements as a supplementary technique following mepivacaine inferior alveolar nerve block in volunteers $[\underline{1}, \underline{3}]$ and patients with irreversible pulpitis [11]. To the best of knowledge, no adult study has compared articaine and mepivacaine with epinephrine. The current study has formally considered this comparison as a potential valuable trail for the extraction of maxillary teeth. The aim of this study was to measure the speed of action and the potency of buccal and palatal infiltrations of $2 \%$ mepivacaine with adrenaline $(1: 100,000)$ and $4 \%$ articaine with adrenaline $(1: 100,000)$ for extraction of maxillary teeth. The null hypothesis was buccal and palatal infiltrations of mepivacaine and articaine have equal anaesthetic efficacy for achieving the maxillary teeth extraction.

\section{MATERIAL AND METHODS Subjects and methods}

This clinical trial was conducted from February 22, 2015, to June 1, 2016 in the Oral and Maxillofacial Department at Taibah Dental College. The study was approved by the Ethics Committee of Taibah University, College of Dentistry, Madinah AlMunawwarah, Saudi Arabia under a number of protocol, registration: IORG0008371. Inclusion and exclusion criteria were set out prior to the recruitment process. Inclusion criteria involved patients who were aged from 16 to 70 years, having vital tooth for extraction, able to understand and co-operate with the requirements of protocol and willing to give an appropriate written informed consent. The maxillary teeth scheduled for extraction were maxillary teeth with either caries, periodontal disease, pre-prosthetic reason, orthodontics, trauma, or fully erupted wisdom teeth. However, patients with pulpitis were included in this study and given the full right of withdrawal at any time if they felt unbearable pain during the application of electrical pulp testing at the baseline. Patients excluded from this study if they were allergic to local anaesthetics, having no contralateral teeth, having crowned/heavily filled teeth, having non-vital or multiple teeth for extraction and those who were unable to complete the dental extraction. A Study information sheet was available for every patient to read, understand and ask before they signed the consent form, after reading the information study sheets and signing the related consent form. Two regimens were randomly administered over one visit. Randomization was achieved by an independent researcher.

Patients, in treatment group 1, received mepivacaine buccal and palatal infiltrations - $2 \%$ mepivacaine with 1:100,000 epinephrine injection solution (Septodont, Saint-Maur-des-Fossés, Franc, France). Patients in treatment group 2 received articaine buccal and palatal infiltrations - articaine hydrochloride $4 \%$ with 1:100,000 epinephrine (Septodont, Saint-Maur-desFossés, Franc, France. The local anaesthetic needle (details of syringe, needle and technique) was inserted at the depth of the sulcus adjacent to the apical of the tooth listed for extraction and advanced 4 to $7 \mathrm{~mm}$ until an adequate bony contact is achieved. $1.4 \mathrm{ml}$ mepivacaine $2 \%$ or articaine $4 \%$ with epinephrine 1:100,000, was delivered slowly over $40 \mathrm{sec}$ after aspiration plus a $0.4 \mathrm{ml}$ mepivacaine or articaine infiltration in the hard palate $5 \mathrm{~mm}$ far from gingival margin over $20 \mathrm{sec}$. No anaesthetic solution was deposited as the needle was advanced to the target site in either regimen. Both patients and the researcher testing anaesthetic effectiveness were not aware to which local anaesthetic buccal infiltration regimen, was administered.

All injections were given by the same operator. Standard aspirating dental cartridge syringes (ATI, A. Titan Instruments, Inc., Orchard Park, New York, USA) fitted with 27 -gauge, $21 \mathrm{~mm}$ short needles (27 gauge, $0.4 \times 21 \mathrm{~mm}, \mathrm{C}-\mathrm{K}$ Ject, C-K DENTAL IND. CO.,LTD., Seoul, Korea) were used for buccal and palatal infiltrations.

The efficacy of pulp anaesthesia was determined objectively for maxillary teeth listed for extraction by 
electronic pulp testing. This was performed with an Analytic Technology Pulp Tester (Analytic Technology Redmond, Washington, USA). Testing was performed at baseline twice then at the following registration points: 2, 4, 6, 8, and 10 minutes after injection. At any point of trial $(10 \mathrm{~min})$, the anesthetized tooth becomes unresponsive for maximal pulp stimulation (64 reading), the extraction was carried out. After 10 min of injection of local anaesthesia, if the anesthetized tooth is still positively responsive to electrical pulp tester, the second cartridge of local anaesthetic was administered. In order to validate the pulp tester readings, a control unanesthetized tooth on the contralateral side of the maxillae was also tested at base line and at intervals in the study. Anaesthetic success was defined when two or more consecutive episodes of maximal pulp stimulation (64 reading) without sensation were recorded. The onset of anaesthesia was determined after the procedure as the time of the first of two consecutive maximal pulp stimulations without sensation [3]. The duration of anaesthesia will be the time from onset to the last 64 reading without sensation, or the end of the study period, whichever comes first.

\section{Statistical analysis}

Sample size calculation was made for this study based on a study by Mittal et al. [12]. A sample size of 45 in each group would have $90 \%$ power to detect a difference in means of 1.24 for onset time of pulpal anaesthesia (the difference between the mepivacaine group mean of 4.22 and articaine group mean of 2.98) assuming that the common standard deviation is 1.19 using a two group t-test with a 0.05 twosided significance level. In the study, $10 \%$ of patients allocated to treatment groups were lost to follow-up. A total sample size of 100 patients, aged between 16 to 70 years old, were recruited for this study.

Data were entered and analysed in statistical software package SPSS (SPSS 17.0, SPSS Inc., Chicago, USA). Cross tabulation test was used to determine the number of individuals who achieved two consecutive 64 readings in each treatment and the number of 64 readings at time intervals post injection independent sample t-test was used to compare the mean onset time of pulpal anaesthesia and extraction between the mepivacaine and articaine. Correlation coefficients were calculated to evaluate the relationship between number of patients recording maxillary tooth pulp anaesthesia ( $1 \times 64$ stimulation without sensation) with time after mepivacaine and articaine buccal infiltration. Parametric data for onset time of anaesthesia were expressed as mean and standard deviation (M [SD]). Statistical significance level was defined at $\mathrm{P}=0.05$.

\section{RESULTS}

One-hundred adult patients were recruited in this study. Six patients dropped out the study because they met the criteria of exclusion (four patients had crowned/heavily filled teeth and two had no contralateral teeth). Moreover, 4 patients were excluded due to faint following local anaesthetic injection (two patients from mepivacaine regimen and two from articaine regimen) and were excluded consequently according to study protocol and official clearances. The final sample size included 90 patients aged between 16 to 70 years old (37 [12.75] years).

\section{Anaesthetic success}

Overall, 85 patients in this study secured anaesthetic success for maxillary teeth following pulp testing after articaine and mepivacaine regimens within 10 min and they had successful extraction. However, there were 5 patients with failed dental anaesthesia who did not achieve the anaesthetic success within the study duration time $(10 \mathrm{~min})$ and an additional local anaesthetic was administered. There was one patient in articaine group and 4 patients in mepivacaine group. It was considered appropriate to use nonparametric tests to quantify the number of episodes with no responses to maximal pulp stimulation (64 reading), termed anaesthetic success.

Crosstabs analysis was carried out to obtain the numbers and percentages of patients in both groups. Table 1 summarises the overall outcome of the anaesthetic success for the pulp of maxillary teeth of the 90 patients who participated in the study. In Table 1, the anaesthetic success represents "no response to maximal electronic pulp stimulation (64 reading)", and the anaesthetic failure represents "positive response to electric pulp stimulation". Articaine buccal infiltration (articaine regimen) achieved significantly similar number of episodes of no response to maximal stimulation of maxillary teeth pulp anaesthesia (64 reading) compared to mepivacaine buccal infiltration (mepivacaine regimen) at $2 \mathrm{~min}(17.8 \%$ vs. $20 \%$ respectively, $\mathrm{P}=0.035)$.

\section{Onset of the maxillary teeth pulp anaesthesia and extraction}

The range onset of pulpal anaesthesia and extraction of maxillary teeth in this study was from 2 to 14 minutes. Table 2 reveals that the mean onset time of anaesthesia and extraction of maxillary teeth using pulp testing after articaine buccal infiltration 
Table 1. Number and percentages of anaesthetic successes at time interval for maxillary teeth pulp anaesthesia following articaine and mepivacaine buccal infiltration in 90 adult patients

\begin{tabular}{|c|c|c|c|c|c|c|c|}
\hline \multirow{2}{*}{$\begin{array}{l}\text { Anaesthetic success } \\
\text { at time interval }\end{array}$} & $2 \mathrm{~min}$ & $4 \mathrm{~min}$ & $6 \mathrm{~min}$ & $8 \mathrm{~min}$ & $10 \mathrm{~min}$ & $>10 \mathrm{~min}$ & Total \\
\hline & $\mathbf{N}(\%)$ & $\mathbf{N}(\%)$ & $\mathbf{N}(\%)$ & $\mathbf{N}(\%)$ & $\mathbf{N}(\%)$ & $\mathbf{N}(\%)$ & $\mathbf{N}(\%)$ \\
\hline Articaine regimen & $32(71.1)$ & $8(17.8)$ & $3(6.7)$ & $1(2.2)$ & $0(0)$ & $1(2.2)$ & $45(100)$ \\
\hline Mepivacaine regimen & $23(51.1)$ & $9(20)$ & $7(15.6)$ & $2(4.4)$ & $0(0)$ & $4(8.9)$ & $45(100)$ \\
\hline P-value & 0.052 & $0.035^{\mathrm{a}}$ & 0.138 & 0.167 & 0.167 & 1 & \\
\hline
\end{tabular}

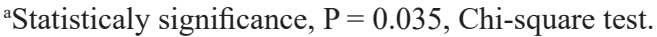

$\mathrm{N}=$ number of patients.

Table 2. Comparisons between mean onset time of pulpal anaesthesia and extraction of the patients for mepivacaine and articaine infiltration groups

\begin{tabular}{l|l|c|c|c|c}
\hline \multicolumn{2}{c|}{ Groups } & $\begin{array}{c}\text { Number of } \\
\text { patients }\end{array}$ & $\begin{array}{c}\text { Mean (SD), } \\
\text { min }\end{array}$ & $\begin{array}{c}\text { t-test } \\
(\mathbf{d f}=\mathbf{8 8})\end{array}$ & \multirow{2}{*}{ P-value } \\
\hline \multirow{2}{*}{$\begin{array}{l}\text { Anaesthesia and } \\
\text { extraction onset time }\end{array}$} & Articaine regimen & 45 & $2.98(1.98)$ & \multirow{2}{*}{2.22} & \multirow{2}{*}{$0.03^{\mathrm{a}}$} \\
\cline { 2 - 4 } & Mepivacaine regimen & 45 & $4.22(3.17)$ & & \\
\hline
\end{tabular}

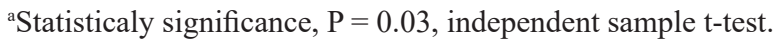

$\mathrm{SD}=$ standard deviation; $\mathrm{df}=$ degree of freedom .

(articaine regimen: $2.98 \quad[1.98] \quad \min )$ was the mepivacaine and articaine buccal infiltration significantly faster than after mepivacaine buccal groups $(\mathrm{P}=0.03)$ (Table 2, Figure 1).

infiltration (mepivacaine regimen: 4.22 [3.17] $\mathrm{min}$ ). It was found that patients in the articaine buccal The application of t-test revealed that there were infiltration group recorded faster onset time of action significant differences in the mean onset time regarding anaesthesia and teeth extraction than of pulpal anaesthesia and extraction between patients in mepivacaine buccal infiltration group.

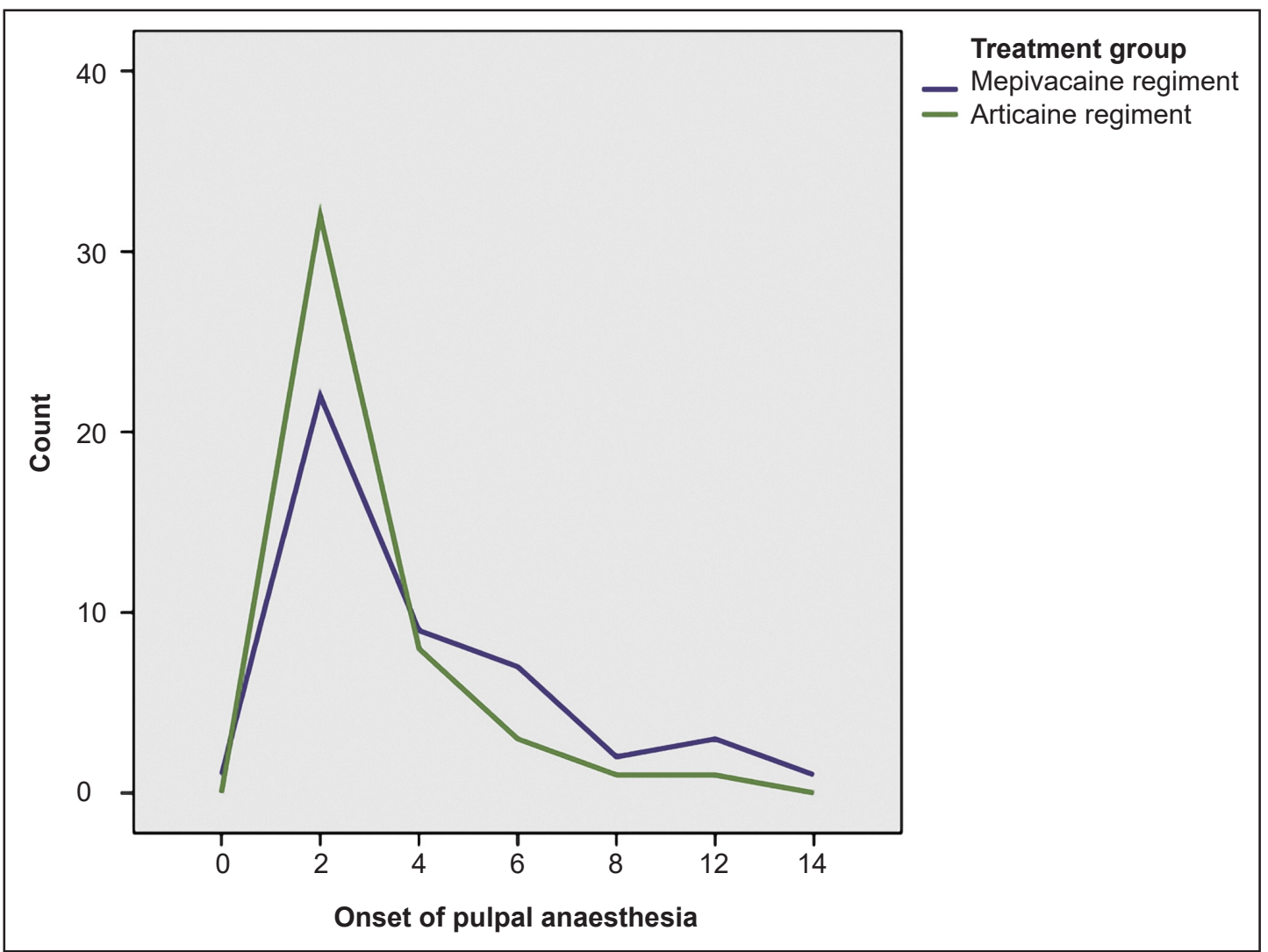

Figure 1. Number of patients recording pulpal anaesthesia in maxillary teeth (1 x 64 stimulation without sensation) with time after mepivacaine and articaine buccal infiltration. 


\section{DISCUSSION}

Few studies in the literature provided significant evidence about the superiority of articaine over mepivacaine for dental anaesthesia $[\underline{1}, \underline{3}, 13-17]$. The present study's findings show the using articaine or mepivacaine buccal infiltrations provided similar success of maxillary teeth anaesthesia at 2 min until $10 \mathrm{~min}$ post injection. However, articaine buccal injection had faster onset time and better potency of action compared to mepivacaine buccal injection for maxillary teeth extraction. The mean onset of maxillary teeth pulp anaesthesia was significantly quicker in articaine regimen (2.98 $\mathrm{min}$ ) compared to mepivacaine regimen $(4.22 \mathrm{~min})$. Our findings are consistent with the results from the recent Cochrane study conducted by St George et al. [4] to compare the success of anaesthesia amongst different local anaesthetic agents used in dental clinical procedures. For anaesthetic success, there were low-quality evidence suggests that $4 \%$ articaine was superior to $2 \%$ lidocaine for treatment of irreversible pulpitis [4]. Another study by Somuri et al. [15] showed that the routine use of a palatal injection for removal of maxillary premolar teeth may not be required when articaine is used as the local anaesthetic. Moreover, a comparative double blind study was carried out by Kandasamya et al. [16] to evaluate the effectiveness of bony diffusion of articaine and lignocaine for the removal of maxillary teeth without the need for palatal injection. The results of this study indicate that articaine 4\% with epinephrine 1:100,000 produced more effective buccal vestibule-palatal anaesthesia than the $2 \%$ lignocaine with 1:80,000, when an interval of $10 \mathrm{~min}$ was allowed. Articaine $4 \%$ is superior in comparison to $2 \%$ lignocaine and possess the characteristics of superior bony diffusion and there is no absolute necessity to use palatal infiltration for the removal of maxillary teeth in accordance with previous studies. Hawkins and Moore [17] reported that the clinical advantages of articaine infiltration including quicker onset of pulp anaesthesia, longer duration of action, in addition to a greater diffusing property over lidocaine local anaesthetic solution.

However, a study by Darawade et al. [18] was conducted on 50 patients to compare the potency of $4 \%$ articaine and $2 \%$ lignocaine in the orthodontic extraction. Patients, who participated in this study, were in age ranged from 15 to 25 , and listed for orthodontic maxillary extraction. The results of Darawade et al. study [18] revealed that the articaine was clinically more potent and has faster onset time than lignocaine but this did not achieve a statistical significance. Patients in articaine group had maxillary extraction without palatal injections, whereas in the lignocaine were required. Similarly, Fan et al. [19] found that the use of articaine as local anaesthetic for the extraction of maxillary teeth does not require a palatal injection to complete the extraction.

In this study, the author recorded one failure dental anaesthesia in the articaine group and four failure ones in the mepivacaine group. This finding might raise the question regarding the strength of the local anaesthetic agents used in this study. One can say the depth of local anaesthesia can be affected either by the volume of the injected solution or its strength [1]. A study by Abazarpoor et al. [20] reported that the use of different volumes of articaine for inferior alveolar nerve block for molar teeth with symptomatic irreversible pulpitis did not achieve $100 \%$ anaesthetic success. However, injection of $3.6 \mathrm{ml}$ articaine scored a significant higher success rate than $1.8 \mathrm{ml}$.

A double-blind crossover randomized clinical trial was conducted to compare the potency of two concentrations of articaine, $2 \%$ and $4 \%$ with 1:200,000 epinephrine, for removal of lower third molar. The findings of this study stated that the both strengths of articaine were effective and safe during the process of surgical extraction. These differences were not statistically significant $(\mathrm{P}<0.05)$ [21]. This study also showed that the number of patients who had successful anaesthesia after 2 min were 32 in articaine group and 23 in mepivacaine group. On the other hand, the fast onset time of anticline can be explained by its unique chemical structure. The thiophene ring of articaine increases its liposolubility, making it more effective than mepivacaine in crossing lipid barriers [22-24]. This characteristic accelerated the diffusion of the articaine molecules through the nerve ending membranes and consequently a rapid blocking of sodium channels was obtained $[\underline{1}, \underline{3}$, 25-35].

\section{CONCLUSIONS}

Articaine is an effective anaesthetic with a rapid onset, comparable to mepivacaine in infiltrative techniques used for maxillary teeth extraction. However, articaine has clinically achieved faster dental anaesthesia and earlier teeth extraction than mepivacaine. So, articaine can be the local anaesthetic of first choice in oral surgery. 


\section{ACKNOWLEDGMENTS AND DISCLOSURE STATEMENTS}

Acknowledgments to individuals who contributed to the research and the article preparation at a level that did not qualify for authorship. This may include technical help or participation in a clinical study. Authors are responsible for obtaining written permission from persons listed by name.

The author report no conflicts of interest related to this study.

\section{REFERENCES}

1. Gazal G, Alharbi AM, Al-Samadani KH, Kanaa MD. Articaine and mepivacaine buccal infiltration in securing mandibular first molar pulp anesthesia following mepivacaine inferior alveolar nerve block: A randomized, doubleblind crossover study. Saudi J Anaesth. 2015 Oct-Dec;9(4):397-403. [Medline: 26543456] [PMC free article: 4610083] [doi: 10.4103/1658-354X.159463]

2. Gazal G, Fareed WM, Zafar MS, Al-Samadani KH. Pain and anxiety management for pediatric dental procedures using various combinations of sedative drugs: A review. Saudi Pharm J. 2016 Jul;24(4):379-85. [Medline: 27330369] [PMC free article: 4908057] [doi: 10.1016/i.jsps.2014.04.004]

3. Gazal G. Comparison of speed of action and injection discomfort of $4 \%$ articaine and $2 \%$ mepivacaine for pulpal anesthesia in mandibular teeth: A randomized, double-blind cross-over trial. Eur J Dent. 2015 Apr-Jun;9(2):201-6. [Medline: 26038650] [PMC free article: 4439846] [doi: 10.4103/1305-7456.156811]

4. St George G, Morgan A, Meechan J, Moles DR, Needleman I, Ng YL, Petrie A. Injectable local anaesthetic agents for dental anaesthesia. Cochrane Database Syst Rev. 2018 Jul 10;7:CD006487. doi: 10.1002/14651858.CD006487.pub2. [Medline: 29990391] [doi: 10.1002/14651858.CD006487.pub2]

5. Kambalimath DH, Dolas RS, Kambalimath HV, Agrawal SM. Efficacy of $4 \%$ Articaine and $2 \%$ Lidocaine: A clinical study. J Maxillofac Oral Surg. 2013 Mar;12(1):3-10. [Medline: 24431806] [PMC free article: 3589513] [doi: 10.1007/s12663-012-0368-4]

6. Kanaa MD, Whitworth JM, Corbett IP, Meechan JG. Articaine buccal infiltration enhances the effectiveness of lidocaine inferior alveolar nerve block. Int Endod J. 2009 Mar;42(3):238-46. [Medline: 19228214] [doi: $10.1111 / \mathrm{j} .1365-2591.2008 .01507 . x$ ]

7. Haas DA, Harper DG, Saso MA, Young ER. Comparison of articaine and prilocaine anesthesia by infiltration in maxillary and mandibular arches. Anesth Prog. 1990 Sep-Oct;37(5):230-7. [Medline: 2096746] [PMC free article: 2148603]

8. Luqman U, Majeed Janjua OS, Ashfaq M, Irfan H, Mushtaq S, Bilal A. Comparison of articaine and lignocaine for uncomplicated maxillary exodontia. J Coll Physicians Surg Pak. 2015 Mar;25(3):181-4. [Medline: 25772957]

9. Snoeck M. Articaine: a review of its use for local and regional anesthesia. Local Reg Anesth. 2012;5:23-33. [Medline: 22915899] [PMC free article: 3417979] [doi: 10.2147/LRA.S16682]

10. Nusstein J, Reader A, Beck FM. Anesthetic efficacy of different volumes of lidocaine with epinephrine for inferior alveolar nerve blocks. Gen Dent. 2002 Jul-Aug;50(4):372-5; quiz 376-7. [Medline: 12640855]

11. Kanaa MD, Whitworth JM, Meechan JG. A prospective randomized trial of different supplementary local anesthetic techniques after failure of inferior alveolar nerve block in patients with irreversible pulpitis in mandibular teeth. J Endod. 2012 Apr;38(4):421-5. [Medline: 22414822] [doi: 10.1016/j.joen.2011.12.006]

12. Mittal M, Sharma S, Kumar A, Chopra R, Srivastava D. Comparison of Anesthetic Efficacy of Articaine and Lidocaine During Primary Maxillary Molar Extractions in Children. Pediatr Dent. 2015 Nov-Dec;37(7):520-4. [Medline: 26883609]

13. Kanaa MD, Meechan JG, Corbett IP, Whitworth JM. Speed of injection influences efficacy of inferior alveolar nerve blocks: a double-blind randomized controlled trial in volunteers. J Endod. 2006 Oct;32(10):919-23. [Medline: 16982264] [doi: 10.1016/j.joen.2006.04.004]

14. Kanaa MD, Whitworth JM, Corbett IP, Meechan JG. Articaine and lidocaine mandibular buccal infiltration anesthesia: a prospective randomized double-blind cross-over study. J Endod. 2006 Apr;32(4):296-8. [Medline: 16554198] [doi: 10.1016/j.joen.2005.09.016]

15. Somuri AV, Rai AB, Pillai M. Extraction of permanent maxillary teeth by only buccal infiltration of articaine. J Maxillofac Oral Surg. 2013 Jun;12(2):130-2. [Medline: 24431829]

16. Kandasamya S, Elangovanb R, Johnb RR, Kumar CN. Removal of maxillary teeth with buccal $4 \%$ articaine without using palatal anaesthesia - A comparative double blind study. Journal of Oral and Maxillofacial Surgery, Medicine, and Pathology. 2015 Mar;27(2):154-8. [doi: 10.1016/i.ajoms.2013.12.001]

17. Hawkins JM, Moore PA. Local anesthesia: advances in agents and techniques. Dent Clin North Am. 2002 Oct;46(4): 719-32, ix. [Medline: 12436827] [doi: 10.1016/S0011-8532(02)00020-4]

18. Darawade DA, Kumar S, Budhiraja S, Mittal M, Mehta TN. A clinical study of efficacy of 4\% articaine hydrochloride versus 2\% lignocaine hydrochloride in dentistry. J Int Oral Health. 2014 Sep;6(5):81-3. [Medline: 25395799] [PMC free article: $\underline{4229836]}$ 
19. Fan S, Chen WL, Yang ZH, Huang ZQ. Comparison of the efficiencies of permanent maxillary tooth removal performed with single buccal infiltration versus routine buccal and palatal injection. Oral Surg Oral Med Oral Pathol Oral Radiol Endod. 2009 Mar;107(3):359-63. [Medline: 18996033] [doi: 10.1016/j.tripleo.2008.08.025]

20. Abazarpoor R, Parirokh M, Nakhaee N, Abbott PV. A Comparison of Different Volumes of Articaine for Inferior Alveolar Nerve Block for Molar Teeth with Symptomatic Irreversible Pulpitis. J Endod. 2015 Sep;41(9):1408-11. [Medline: 26149210] [doi: 10.1016/j.joen.2015.05.015]

21. Senes AM, Calvo AM, Colombini-Ishikiriama BL, Gonçalves PZ, Dionísio TJ, Sant'ana E, Brozoski DT, Lauris JR, Faria FA, Santos CF. Efficacy and Safety of 2\% and 4\% Articaine for Lower Third Molar Surgery. J Dent Res. 2015 Sep;94(9 Suppl):166S-73S. [Medline: 26202994] [doi: 10.1177/0022034515596313]

22. Malamed SF, Gagnon S, Leblanc D. Articaine hydrochloride: a study of the safety of a new amide local anesthetic. J Am Dent Assoc. 2001 Feb;132(2):177-85. [Medline: 11217590] [doi: 10.14219/jada.archive.2001.0152]

23. Becker DE, Reed KL. Essentials of local anesthetic pharmacology. Anesth Prog. 2006 Fall;53(3):98-108; quiz 109-10. [Medline: 17175824] [PMC free article: 1693664] [doi: 10.2344/0003-3006(2006)53[98:EOLAP]2.0.CO;2]

24. Uckan S, Dayangac E, Araz K. Is permanent maxillary tooth removal without palatal injection possible? Oral Surg Oral Med Oral Pathol Oral Radiol Endod. 2006 Dec;102(6):733-5. Epub 2006 Mar 20. Erratum in: Oral Surg Oral Med Oral Pathol Oral Radiol Endod. 2007 Apr;103(4):580. [Medline: 17138173] [doi: 10.1016/j.tripleo.2005.12.005]

25. Kakroudi SH, Mehta S, Millar BJ. Articaine hydrochloride: is it the solution? Dent Update. 2015 Jan-Feb; 42(1):88-90, 92-3. [Medline: 26062283] [doi: 10.12968/denu.2015.42.1.88]

26. Shurtz R, Nusstein J, Reader A, Drum M, Fowler S, Beck M. Buffered 4\% Articaine as a Primary Buccal Infiltration of the Mandibular First Molar: A Prospective, Randomized, Double-blind Study. J Endod. 2015 Sep;41(9):1403-7. [Medline: 26095381] [doi: 10.1016/j.joen.2015.05.005]

27. Oliveira PC, Volpato MC, Ramacciato JC, Ranali J. Articaine and lignocaine efficiency in infiltration anaesthesia: a pilot study. Br Dent J. 2004 Jul 10;197(1):45-6; discussion 33. [Medline: 15243610] [doi: 10.1038/sj.bdj.4811422]

28. Costa CG, Tortamano IP, Rocha RG, Francischone CE, Tortamano N. Onset and duration periods of articaine and lidocaine on maxillary infiltration. Quintessence Int. 2005 Mar;36(3):197-201. [Medline: 15887505]

29. Lima JL Jr, Dias-Ribeiro E, Ferreira-Rocha J, Soares R, Costa FW, Fan S, Sant'ana E. Comparison of buccal infiltration of $4 \%$ articaine with $1: 100,000$ and $1: 200,000$ epinephrine for extraction of maxillary third molars with pericoronitis: a pilot study. Anesth Prog. 2013 Summer;60(2):42-5. [Medline: 23763558] [PMC free article: 3683879 ] [doi: 10.2344/0003-3006-60.2.42]

30. Malamed SF, Falkel M. Advances in local anesthetics: pH buffering and dissolved CO2. Dent Today. 2012 May;31(5): 88-93; quiz 94-5. [Medline: 22650087]

31. Malamed SF. Articaine versus lidocaine: the author responds. J Calif Dent Assoc. 2007 Jun;35(6):383-5. [Medline: 17849965 ]

32. Al-Samadani KH, Gazal G. Effectiveness of benzocaine in reducing deep cavity restoration and post-extraction stress in dental patients. Saudi Med J. 2015 Nov;36(11):1342-7. [Medline: 26593169] [PMC free article: 4673373] [doi: $10.15537 /$ smj.2015.11.12274]

33. Gazal G, Alharbi R, Fareed WM, Omar E, Alolayan AB, Al-Zoubi H, Alnazzawi AA. Comparison of onset anesthesia time and injection discomfort of $4 \%$ articaine and $\%$ mepivacaine during teeth extractions. Saudi J Anaesth. 2017 Apr-Jun;11(2):152-157. [Medline: 28442952] [PMC free article: 5389232] [doi: 10.4103/1658-354X.203017]

34. Cazaubon Y, Mauprivez C, Feliu C, Binet L, Oget O, Gozalo C, Djerada Z. Population pharmacokinetics of articaine with 1:200,000 epinephrine during third molar surgery and simulation of high-dose regimens. Eur J Pharm Sci. 2018 Mar 1;114:38-45. [Medline: 29197630] [doi: 10.1016/j.ejps.2017.11.027]

35. Al-Mahalawy H, Abuohashish H, Chathoth S, Al-Masoud N, Al-Jandan B. Articaine Versus Lidocaine Concentration in the Palatal Tissues After Supraperiosteal Buccal Infiltration Anesthesia. J Oral Maxillofac Surg. 2018 Feb;76(2):315.e1-315.e7. [Medline: 29102601] [doi: 10.1016/j.joms.2017.10.001]

\section{To cite this article:}

Gazal G.

Is Articaine More Potent than Mepivacaine for Use in Oral Surgery?

J Oral Maxillofac Res 2018;9(3):e5

URL: http://www.ejomr.org/JOMR/archives/2018/3/e5/v9n3e5.pdf

doi: $\underline{10.5037 / \text { jomr.2018.9305 }}$ 
Copyright @ Gazal G. Published in the JOURNAL OF ORAL \& MAXILLOFACIAL RESEARCH (http://www.ejomr.org), 30 September 2018.

This is an open-access article, first published in the JOURNAL OF ORAL \& MAXILLOFACIAL RESEARCH, distributed under the terms of the Creative Commons Attribution-Noncommercial-No Derivative Works 3.0 Unported License, which permits unrestricted non-commercial use, distribution, and reproduction in any medium, provided the original work and is properly cited. The copyright, license information and link to the original publication on (http://www.ejomr.org) must be included. 